\section{Audit Rotation And Earnings Quality: An Analysis Using Discretionary Accruals}

\author{
Adalene Olivia Silvestre ${ }^{1, \dagger}$ \\ ${ }^{1}$ Universidade do Vale do Rio dos Sinos, São Leopoldo, RS, Brazil \\ Cristiano Machado Costa ${ }^{2, \Omega}$ \\ ${ }^{2}$ Universidade do Vale do Rio dos Sinos, São Leopoldo, RS, Brazil \\ Clóvis Antônio Kronbauer ${ }^{3, ¥}$ \\ ${ }^{3}$ Universidade do Vale do Rio dos Sinos, São Leopoldo, RS, Brazil
}

\section{ABSTRACT}

This article aims to measure the effect of the audit firm rotation on the earnings quality of Brazilian public companies listed on BM\&FBOVESPA in the period from 2008 to 2015. We use discretionary accruals as a measure of earnings quality, using two approaches: earnings management and the estimation errors. Results show that audit firm rotation reduced the volume of discretionary accruals and, thus, increases the earnings quality, when these are measured from the perspective of earnings management. However, we do not observe the effect of audit firm rotation on earnings quality when the discretionary accruals are measured from the perspective of accounting estimation errors. The results also show that companies that rotate audit firms voluntarily have greater discretionary accruals and, consequently, lower earnings quality.

Keywords: Audit rotation. Earnings quality. Discretionary accruals. Earnings management. Estimation errors.

\section{INTRODUCTION}

The results disclosed by companies depend as much on their resource management performance, as on the way the accounting system measures this performance. (DECHOW; GE; SCHRAND, 2010). The formation of the results according to the accounting standards contains provisions so that the results demonstrate the company's real performance, allowing the competence of the facts to be respected regardless of the effective movement of cash flows (JOHNSON; KHURANA; REYNOLD, 2002). If, on the one hand, the provisions allow the company to report its real performance, on the other, the provisions increase the possibility of occurrence of estimation errors, whether intentional or not (KRISHNAN, 2003).

In this context, the independent auditor emerges to reduce the asymmetry of information between the company and those that are external to it. In order for the auditor to fulfill their role, their work is conditioned
Corresponding author:

${ }^{\dagger}$ Universidade do Vale do Rio dos Sinos, São Leopoldo, RS, Brazil

E-mail: adasilvestre@gmail.com

$\Omega$ Universidade do Vale do Rio dos Sinos, São Leopoldo, RS, Brazil

E-mail: cristianocosta@unisinos.br

${ }^{*}$ Universidade do Vale do Rio dos Sinos, São Leopoldo, RS, Brazil

E-mail: clovisk@unisinos.br

Received: 05/26/2017.

Revised: 07/25/2017.

Accepted: 11/06/2017.

Published Online: 06/26/2018.

DOI: http://dx.doi.org/10.15728/bbr.2018.15.5.1 
on their independence from the audited company. It is an important factor for the disclosure of quality accounting statements (CHEN, LIN, LIN, 2008).

The occurrence of financial scandals involving large corporations and their audits led society and regulators to question the independence of the audit (AZEVEDO; COSTA, 2012). These scandals, which have been partially motivated or, at least, inadequately detected by independent auditors, have prompted academics, regulators and professionals to discuss rules that require the exchange of audit firm after a number of years, which are beneficial to society (ANINAT; BUSTOS; RIUTORT, 2016).

Although the focus of the discussion on audit rotation lies in maintaining auditor independence, Myers, J., Myers, L. and Omer (2003) suggest that the central point to be considered about the tenure of the auditor's relationship with the client firm is the earnings quality. In this sense, the independence of the auditor is understood as an element that affects the earnings quality. Schipper and Vincent (2003) argue that earnings quality relates to the usefulness of information for decision-making.

Brazil has peculiar characteristics in relation to the subject, since, to this day it was one of the few countries to make audit firm rotation mandatory. Considering that the Brazilian scenario represents an excellent opportunity to investigate audit rotation, the present study seeks to answer the following question: what is the effect of the audit firm rotation on earnings quality by the companies? Therefore, the objective of the research is to analyze the effect of the audit firm rotation on the earnings quality of Brazilian publicly traded companies. Specifically, we seek to verify if the effect of audit firm rotation on the earnings quality is different when performed in a mandatory manner compared to voluntary exchange.

The present research brings contributions to the international market by highlighting the effects of audit rotation based on a scenario of regulated audit firm rotation. The Brazilian experience may be of interest to innumerous nations, as is the case of the nations of the European Union. Recently, Brazil approved new auditing rules, which, among other determinations, regulates the compulsory audit firm rotation in one of the largest economic regions in the world. This research also complements other important national and international research carried out on the subject. In addition, the results of the research are of interest to the Brazilian regulatory agencies, enriching the discussion about the maintenance of mandatory audit firm rotation.

Finally, with the focus on the usefulness of the information, the results presented are of interest to those who use accounting statements, whether they are investors or other interested parties. The results of the research evidence factors associated with the earnings quality, information of interest for the decision-making process, since, according to Schipper and Vincent (2003), investment decisions based on low earnings quality can lead to poor allocation of funds for investors, in addition to masking the deterioration of solvency, leading creditors to erroneously continue to lend resources to the company.

\section{LITERATURE REVIEW}

\subsection{IndePENDENT AUdit ANd AUdit Rotation}

The agency theory acknowledges the importance of independent auditing to minimize agency problems. The independent auditor reduces information asymmetry between the agent and the principal, monitoring agent behavior and, it is recognized as one of the main monitoring mechanisms to regulate conflict of interests and reducing agency costs. (PIOT, 2001). The independent audit helps to minimize agency problems by evaluating and expressing an opinion on whether the accounting statements are in compliance with current standards and free of material misstatement, since the auditor should form an opinion on whether the accounting statements taken as a whole do not present material misstatements, 
BBR

regardless of whether they were caused by fraud or error (FEDERAL COUNCIL OF ACCOUNTING (CFC), 2016).

For the audit to fulfill its role, it is essential that the auditor's work is independent. According to Kim, Lee and Lee (2015), independence is considered one of the key factors in increasing the quality of audited accounting statements. With a focus on auditor independence, mandatory audit firm rotation is proposed as a means to improve the quality of the audit and, consequently, of the financial statement (CAREY; SIMNETT, 2006).

The proposal divides opinions. On the one hand, it is argued that the quality of the audit will be jeopardized by the long relationship with the auditor, mainly due to the threat to the auditor's independence and objectivity (CARCELLO; NAGY, 2004). Supporters of audit rotation believe that declining independence can lead the auditor to support more aggressive accounting choices and result in failures detecting relevant material misstatements (MYERS, J.; MYERS, L.; OMER, 2003). On the other hand, it is argued that audit quality is lower in the initial years and increases over the years, based on the knowledge acquired by the auditor about the company's business (CARCELLO; NAGY, 2004). It is believed that the auditor conducting the audit for the same client for consecutive years learns about the critical points of the company that may require special attention (GUL; FUNG; JAGGI, 2009).

In the international scenario, discussions about auditing firm rotation are far from over. Recently, the European Union introduced a reform of the audit legislation which, among other things, deals with the compulsory audit firm rotation. According to Deloitte (2014), the new legislation makes mandatory audit firm rotation for entities of public interest, being implemented by member states from 2016 . However, mandatory audit firm rotation is subject to a transition period and the requirements will be introduced over a longer period (DELOITTE, 2014).

Some countries, such as Spain, Italy, Singapore and South Korea, have adopted the mandatory audit firm rotation. We should note, however, that in South Korea the rotation was suspended in the period of convergence with international accounting standards; in Singapore the requirement for publicly traded banks was suspended during the recent financial crisis and; Spain abandoned the practice after seven years of obligation (INSTITUTO DOS AUDITORES INDEPENDENTES DO BRASIL (IBRACON), 2014). In the United States, auditing firm rotation is not mandatory. As a measure to increase auditor independence, Sarbanes-Oxley Act (SOX) determines that the partner responsible for audit must be replaced every five years.

In Brazil, CVM Instruction $\mathrm{n}^{\circ}$. 308/99 made the audit firm rotation mandatory for all companies listed on stock exchanges. With the adoption of mandatory audit firm rotation, the CVM sought to guarantee the auditor's independence from the audited company and the quality of its audit (ASUNCTION; CARRASCO, 2008). CVM Instruction 308/99 establishes that the audit firm cannot provide services for the same client for a period of more than five years, requiring a minimum interval of three years for the rehiring.

During the period of convergence to international standards, the mandatory audit rotation was suspended by CVM Deliberation 549/08 and CVM Deliberation 669/11. The CVM acknowledged that "in the period of adaptation to the dispositions of Law 11638/07, mandatory auditors rotation could represent undesirable instability, both for the entities and for the independent auditors" (COMISSÃO DE VALORES MOBILIÁRIOS (CVM), 2008). Based on the effective date of the instruction that requires the audit firm to rotate, 2009 would close yet another round of auditor rotation for most publicly traded companies. The CVM allowed the non-substitution of audit firm until the date of issuance of the independent audit report for the financial statements for the year 2011, for companies closing their fiscal year on a date coinciding with the calendar year, and 2012 for the other companies. 
In 2011, CVM Instruction $n^{\circ} .509$ made it possible to extend the period of mandatory audit firm rotation to ten years. To extend the term, the audited company must have a Statutory Audit Committee in permanent operation, and the auditor must be a legal entity, among other normative provisions.

Finally, we note that the relationship between the audit firm and the company can be terminated voluntarily, by decision of the parties. For example, voluntary rotation can occur due to conflicts between the auditor and the company. DeFond and Subramanyam (1998) tested whether voluntary audit rotation is associated with the auditor's preference for more conservative accounting choices. The authors concluded that litigation risks lead auditors to more conservative accounting choices, also that companies voluntary switch audits in the hope that the new auditor will be more reasonable.

\subsection{EARNINGS QUALITY}

The formation of results according to accounting standards contains provisions and deferrals so that the results disclosed show the real performance of the company, allowing to overcome the limitations inherent to the cash flow (JOHNSON; KHURANA; REYNOLD, 2002). However, such provisions and deferrals may generate uncertainties and inaccuracies in the application of accounting standards, leading to estimation errors. In addition, the flexibility of accounting standards can be used opportunistically by the company's management to maximize its results, generating lower quality financial statements. (JENKINS; VELURY, 2012). In summary, the quality of disclosed earnings by companies depends as much on its performance as it does on the way the accounting system measures this performance (DECHOW; GE; SCHRAND, 2010).

Among the various measures available to capture earnings quality, accruals stand out. According to Chan et al. (2006), accruals represent the difference between the accounting earning and its underlying cash flow. Accruals are composed of two distinct parts, the normal accruals and the abnormal accruals. While the first represents the adjustments that reflect the company's fundamental performance, the second captures the distortions induced by the application of accounting standards or the earnings management (DECHOW; GE; SCHRAND, 2010). According to Dechow, Ge and Schrand (2010, p. 358), "The general interpretation is that if the normal component is modeled correctly, then the abnormal component represents a distortion that is of inferior quality."

We use the traditional accruals calculation models to estimate the normal levels of accruals, whereas the residuals of these models are used as a measure of abnormal accruals (DECHOW; GE; SCHRAND, 2010). In this sense, the abnormal accruals, also termed as discretionary accruals, can capture both the earnings management and the estimation errors. While the former comes up from incentives to manage results, the latter arises from management lags and environmental uncertainties (FRANCIS et al., 2005). Both, estimation errors or earnings management, are inverse to the earnings quality (BAXTER; COTTER, 2009).

Earnings management is regarded as an inverse measure of the earnings quality by representing a deliberate intervention in the financial statements, negatively impacting the earnings quality (BAXTER; COTTER, 2009). In the extensive literature about earnings management and earnings quality, the Jones model (1991) and the modified Jones model by Dechow, Sloan, and Sweeney (1995) have been widely used to capture earnings management.

On estimation errors, Baxter and Cotter (2009) argue that estimation errors of accruals and subsequent corrections imply a reduction in the earnings quality. Unlike earnings management models, the estimation error models do not bother to distinguish intentional errors from unintentional errors. That is, the source of the error is irrelevant in this approach. 
BBR

15,5

414

(FRANCIS et al., 2005). Dechow and Dichev (2002) have modeled accruals as a function of past, present, and future cash flow. Subsequently, McNichols (2002) extended the model proposed by Dechow and Dichev (2002).

\subsection{Emipirical Studies about Audit Rotation and EARnings Qual-} ITY

Johnson, Khurana and Reynold (2002) identified that the short audit tenure is associated with greater total discretionary accruals. They also observed greater intervention of managers in the disclosed earnings and lower earnings quality in the short relationships between auditor and client. On the other hand, the tests referring to the long audit tenure did not produce evidences that the long audit tenure is associated with greater discretionary accruals. Thus, unlike the short audit tenure, we cannot say that the long audit tenure is associated with the reduction in earnings quality. According to the authors, it is important to highlight that the results are based on a scenario of unregulated rotation and that, in regulated scenarios, where the relationship time is known, the incentives to the auditors can change significantly.

In their study, Myers, J., Myers, L. and Omer (2003) showed that the magnitude of accruals reduced with the long audit firm tenure. That is, the study showed that the increase in the auditor's relationship time with the company does not lead to a reduction in the earnings quality.

Gul, Fung and Jaggi (2009) evidenced that the earnings quality is lower when the time of the auditor's relationship with the company is shorter and that the specialist auditor reduces the association between the short audit tenure and the low earnings quality. Thus, the authors suggest that the low earnings quality traditionally linked to the short audit tenure may not be due to the short relationship time, but rather because the new auditor is not a specialist in the areas required to serve a specific client.

Based on companies in Taiwan, Chen, Lin and Lin (2008) showed that discretionary accruals have reduced significantly with the increase of the relationship time with the audit firm. Thus, they concluded that their results are inconsistent with the argument that audit rotation can increase the earnings quality.

The findings by Davis, Soo and Trompeter (2009) indicated that both short-term and long-term relationships are associated with the increase of the use of discretionary accruals in the pre SOX period, but the results are not maintained in the post SOX period. The authors found evidence of increased earnings management in the first years of relationship, as well as evidences that the long-term relationship is associated with greater tolerance of auditors in relation to earnings management. However, we can only observe this relationship in the long run when the relationship is older than fifteen years.

The research developed by Harris and Whisenant (2012) selected a sample of countries that adopted the mandatory audit firm rotation. The results indicated that companies in a mandatory rotation environment have lower earnings management, lower management to achieve earnings goals and more timely recognition of losses. Thus, the authors concluded that, on average, the audit markets present greater quality after the adoption of mandatory audit firm rotation.

Consistent with the arguments of the proponents of rotation, the study by Kim, Lee and Lee (2015) demonstrated that the new auditor hired due to mandatory rotation is more likely to issue a modified audit report, in comparison to the auditor who was voluntarily changed by the company. The results also evidenced that companies audited by auditors replaced due to compulsory rotation have, in the first year, lower discretionary accruals and higher quality accruals than those who performed voluntary rotation. 
In the Brazilian scenario, Silva and Bezerra (2010) evidenced that there is a tendency of earnings management to decrease in the year of audit firm rotation. Subsequently, correlation coefficient tests were applied, but these did not allow to affirm that the audit firm rotation is related to the reduction of the earnings management, although some sectors have shown such tendency. Martinez and Reis (2011) demonstrated that the earnings management does not present significant difference due to audit firm rotation. Azevedo and Costa (2012) have evidenced that audit firm rotation does not impact the level of earnings management.

\subsection{DeVelopment of Hypotheses}

In order to analyze the effect of mandatory audit firm rotation and voluntary audit firm rotation on earnings quality, we developed the following hypotheses:

H1: The earnings quality reported by companies, increases with the mandatory audit firm rotation.

H2: The earnings quality reported by companies, increases with the voluntary audit firm rotation.

The construction of both hypotheses allows identifying similarities or differences between the effect of mandatory rotation and voluntary rotation on the earnings quality, contributing to the discussion about the audit firm rotation.

\section{Methodology}

\subsection{Population and Sample}

The population of the present study comprises all publicly traded companies listed on the BM\&FBOVESPA from 2008 to 2015 . We defined the period based on the availability of data, since we required data from the Cash Flow Statement, made widely available only after Law 11.638 / 07. With the aid of the Economática software, we collected data from the Balance Sheet, Income Statement and Cash Flow Statement, and we selected the companies that presented all the necessary data for the survey. Thus, the initial sample selection consisted of 222 companies.

We excluded a total of nineteen companies in the sectors of "finance and insurance", "management of companies and enterprises" and "holding companies" due to their peculiarities. We excluded two other companies because they presented extremely high values of net equity and losses. Furthermore, we extracted data from the independent audit report from the BM\&FBOVESPA website, and fifteen companies were excluded from the sample because they did not have available audit data. After all the adjustments, the final sample comprised of 186 companies.

Finally, we also collected some data for the 2007 exercise to optimize the sample. As we will demonstrate, we required data from year $\mathrm{t}-1$ for the modified Jones model. Thus, we collected the data of the referred exercise so that the discretionary accruals for the year 2008 could be calculated, avoiding that the exercise of 2008 being wasted in these two models.

\subsection{Calculation of Accruals}

The residuals of the accruals models represent discretionary accruals, elements that reduce the earnings quality. Thus, the greater the discretionary accruals, the lower the reported earnings quality. In order to meet the objectives of the study, we selected four different accruals models. The diversification of the models allows that the earnings quality, measured by the residues of the accruals, to be analyzed from different perspectives and based on different information. For example, while the models proposed by Jones (1991) and the modified Jones model by Dechow, Sloan and Sweeney (1995) use Balance Sheet and Income 
BBR

15,5

Statement data and identify the earnings management, the model proposed by Dechow and Dichev (2002) and the Dechow and Dichev model modified by McNichols (2002) use data from Cash Flow Statements and identify the estimation errors, regardless of whether or not they are intentional.

We defined the accruals estimation parameters for each year, for all companies in the sample. With the residuals of each model, we created the variables of the earnings quality for each company, in each year. Exhibit 1 presents the accrual calculation models we used.

\subsection{Definition of Variables and the Regression Model}

The dependent variable, earnings quality (EQ), assumes the value from residuals accruals $\left(\mathcal{E}_{\mathrm{t}}\right)$, calculated according to the models presented previously. We created a variable for the residual of each of the models: acrrualJ, accrualJM, accrualDD and accrualMN to receive the residual of the models Jones (1991), Modified Jones (1995), Dechow and Dichev (2002) and McNichols (2002) respectively, for each company in each year. As in the study by Baxter and Cotter (2009), we use the absolute values of the residuals accruals, that is, the positive and negative sign of the residuals accruals were disregarded.

We added the independent variable rotation to the model to identify whether the audit firm rotation occurred in the year under review. It is a dummy variable that takes value 1 if the audit firm rotation occurred, and 0 otherwise. That is, if the audit firm of year $t$ is different from the one that audited the company in year $t-1$, the rotation rate takes the value of 1 for year $t$.

Initially, we tested the direct relationship between the earnings quality and the audit firm rotation using a simplified version of the regression model, expressed in the specification 1 :

$$
\mathrm{EQ}_{\mathrm{it}}=\alpha+\beta_{1} \text { Rotation }_{\mathrm{it}}+\varepsilon_{\mathrm{it}}
$$

To test the hypotheses $\mathrm{H} 1$ and $\mathrm{H} 2$, we added the voluntary independent variable. This variable identifies the reason for the audit firm rotation, that is, mandatory or voluntary. It is a dummy variable that takes value 1 if the rotation occurred voluntarily, and 0 if it is mandatory. For the classification of the rotation as mandatory or voluntary, we established a criterion that allowed distinguishing one circumstance from the other. We considered as mandatory the rotation that occurred after five years of relationship between the audit firm and the client, and the others were considered voluntary. It should be noted, however, that we considered all rotations as voluntary in the period of suspension of mandatory audit firm rotation.

Exhibit 1. Accruals models

\begin{tabular}{ll}
\hline Jones & $\mathrm{ACC}_{\mathrm{t}} / \mathrm{A}_{\mathrm{t}-1}=\alpha\left(1 / \mathrm{A}_{\mathrm{t}-1}\right)+\beta_{1}\left(\Delta \operatorname{Revt} / \mathrm{A}_{\mathrm{t}-1}\right)+\beta_{2}\left(\mathrm{PPE}_{\mathrm{t}} / \mathrm{A}_{\mathrm{t}-1}\right)+\varepsilon_{\mathrm{t}}$ \\
& $\mathrm{ACC}_{\mathrm{t}}=\Delta \mathrm{CA}_{\mathrm{t}}-\Delta \mathrm{CL}_{\mathrm{t}}-\Delta \mathrm{Cash}_{\mathrm{t}}+\Delta \mathrm{STD}_{\mathrm{t}}-\mathrm{DEP}_{\mathrm{t}}$ \\
\hline Modified Jones & $\mathrm{ACC}_{\mathrm{t}} / \mathrm{A}_{\mathrm{t}-1}=\alpha\left(1 / \mathrm{A}_{\mathrm{t}-1}\right)+\beta_{1}\left(\left(\Delta \operatorname{Rev}_{\mathrm{t}}-\Delta \mathrm{Rec}_{\mathrm{t}}\right) / \mathrm{A}_{\mathrm{t}-1}\right)+\beta_{2}\left(\mathrm{PPE}_{\mathrm{t}} / \mathrm{A}_{\mathrm{t}-1}\right)+\varepsilon_{\mathrm{t}}$ \\
& $\mathrm{ACC}_{\mathrm{t}}=\Delta \mathrm{CA}_{\mathrm{t}}-\Delta \mathrm{CL}_{\mathrm{t}}-\Delta \mathrm{Cash}_{\mathrm{t}}+\Delta \mathrm{STD}_{\mathrm{t}}-\mathrm{DEP} \mathrm{t}_{\mathrm{t}}$ \\
\hline Dechow and Dichev & $\Delta \mathrm{WC}_{\mathrm{t}}=\alpha+\beta_{1} \mathrm{CFO}_{\mathrm{t}-1}+\beta_{2} \mathrm{CFO}_{\mathrm{t}}+\beta_{3} \mathrm{CFO}_{\mathrm{t}+1}+\varepsilon_{\mathrm{t}}$ \\
& $\Delta \mathrm{WC}_{\mathrm{t}}=\Delta \mathrm{AR}_{\mathrm{t}}+\Delta \mathrm{Inventory}_{\mathrm{t}}-\Delta \mathrm{AP}_{\mathrm{t}}-\Delta \mathrm{TP}_{\mathrm{t}}+\Delta$ OtherAssets $_{\mathrm{t}}$ \\
\hline McNichols & $\Delta \mathrm{WC}_{\mathrm{t}}=\alpha+\beta_{1} \mathrm{CFO}_{\mathrm{t}-1}+\beta_{2} \mathrm{CFO}_{\mathrm{t}}+\beta_{3} \mathrm{CFO}_{\mathrm{t}+1}+\Delta \operatorname{Rev}_{\mathrm{t}}+\beta_{2} \mathrm{PPE}_{\mathrm{t}}+\varepsilon_{\mathrm{t}}$ \\
& $\Delta \mathrm{WC}_{\mathrm{t}}=\Delta \mathrm{AR}_{\mathrm{t}}+\Delta$ Inventory $_{\mathrm{t}}-\Delta \mathrm{AP}_{\mathrm{t}}-\Delta \mathrm{TP}_{\mathrm{t}}+\Delta$ OtherAssets $_{\mathrm{t}}$
\end{tabular}

Where: ACC $\mathrm{A}_{\mathrm{t}}$ total accruals; $\mathrm{A}_{\mathrm{t}-1}$ : total assets in $\mathrm{t}-1 \Delta \mathrm{Rev}_{\mathrm{t}}$ : growth in sales; $\mathrm{PPE}_{\mathrm{t}}$ : gross fixed asset; $\Delta \mathrm{CA}_{\mathrm{t}}$ : change in current assets; $\Delta \mathrm{CL}_{\mathrm{t}}$ : change in current liabilities; $\Delta \mathrm{Cash}_{\mathrm{t}}$ : change in cash and cash equivalents; $\Delta \mathrm{STD}_{\mathrm{t}}$ : variation in short-term financing in current liabilities; DEP: depreciation and amortization in the period; $\Delta \operatorname{Rev}_{t}-\Delta \operatorname{Rec}_{t}$ : change in revenue adjusted for changes in receivables in the period; CFO: cash flow from operations; $\Delta \mathrm{WC}_{\mathrm{t}}$ : change in working capital; $\Delta \mathrm{AR}_{\mathrm{t}}$ : change in accounts receivable; $\Delta$ Inventory: change in inventories; $\Delta \mathrm{AP}_{\mathrm{t}}$ : change in accounts payable; $\Delta \mathrm{TP}_{\mathrm{t}}$ : change in taxes payable; $\Delta$ OtherAssets: change in other net assets; $\varepsilon_{t}$ : residuals accruals. In the Dechow and Dichev model and the McNichols mo$\mathrm{del}$, all variables are scaled by average total assets. Source: prepared by the authors. 
In order to verify if the reason for the change influences the earnings quality, we added the voluntary variable to the regression model, giving rise to specification 2:

$$
\mathrm{EQ}_{\mathrm{it}}=\alpha+\beta_{1} \text { Rotation }_{\mathrm{it}}+\beta_{2} \text { Voluntary }_{\mathrm{it}}+\varepsilon_{\mathrm{it}}
$$

We included control variables in the regression model because of the probability of other determinants influencing the earnings quality of companies. Based on previous studies, we included audit and company characteristics that can influence the earnings quality. They are.

We added control variables, giving rise to two other specifications. We added the control variables in specification 3 , except the sector dummies. In specification 4 , we added sector dummies, with this being the complete version of the regression model:

$\mathrm{EQ}_{\mathrm{it}}=\alpha+\beta_{1}$ Rotation $_{\mathrm{it}}+\beta_{2}$ Voluntary $_{\mathrm{it}}+\beta_{3}$ Audit Firm $_{\mathrm{it}}+\beta_{4}$ Tenure $_{\mathrm{it}}+\beta_{5}$ Size $_{\mathrm{it}}+\beta_{6}$ Age $_{\mathrm{it}}$ $+\beta_{7}$ ROA $_{\text {it }}+\beta_{8}$ Leverage $_{\text {it }}+\beta_{9}$ Cash Flow $_{\text {it }}+\beta_{10}$ Growth $_{\text {it }}+\beta_{11}$ Loss $_{\text {it }}+\beta_{12}$ Gross Margin $_{\text {it }}$ $+\beta_{13}$ Operational Cycle $_{\text {it }}+\beta_{14}$ Sector $_{\text {it }} \ldots \beta_{31}$ Sector $_{\text {it }}+\varepsilon_{\text {it }}$

With the help of the Stata Software, we organized the model variables into panel data. Before any calculation for the construction of the variables, we submitted all values data to the winsorizing procedure. Thus, the extreme values of the sample were limited. With the residuals accruals for each company in each year, we estimated the four specifications, from the simplest to the most complete, for each measure of the residuals accruals, totaling sixteen estimates. We estimated each of the four specifications by the methods of ordinary least squares and robust residues. We estimated the models using the pool cross-section format. Variables definitions are presented on Exhibit 2.

Exhibit 2: Control variables

\begin{tabular}{|c|c|c|}
\hline Variable & Justification & Definition \\
\hline Audit Firm & $\begin{array}{l}\text { Large audit firms tend to be more conservative, limiting } \\
\text { extreme accruals (MYERS, J.; MYERS, L.; OMER, 2003). }\end{array}$ & $\begin{array}{l}\text { Dummy. Takes value } 1 \text { if the company is audited } \\
\text { by a Big Four firm, and } 0 \text { otherwise. }\end{array}$ \\
\hline Tenure & $\begin{array}{l}\text { It controls the effect of the relationship time between the audit } \\
\text { firm and the company. }\end{array}$ & $\begin{array}{l}\text { Number of consecutive years in which the } \\
\text { company maintained the same audit firm. }\end{array}$ \\
\hline Size & $\begin{array}{l}\text { Larger companies tend to perform more predictable and stable } \\
\text { operations and, therefore, earnings management and estimation } \\
\text { errors should occur less frequently (DECHOW; DICHEV, } \\
\text { 2002). }\end{array}$ & Log of total assets. \\
\hline Age & $\begin{array}{l}\text { Older companies tend to be more stable (GHOSH; MOON, } \\
\text { 2005). }\end{array}$ & $\begin{array}{l}\text { Number of years in which it has been listed on the } \\
\text { stock exchange. }\end{array}$ \\
\hline ROA & $\begin{array}{l}\text { Controls potential changes in company performance } \\
\text { (JOHNSON; KHURANA; REYNOLD, 2002). It is believed } \\
\text { that the change in the earnings quality is associated to the } \\
\text { change in the company's performance (BAXTER; COTTER, } \\
2009 \text { ). }\end{array}$ & Net profit $_{t} /$ Total Assets $t_{t-1}$ \\
\hline Leverage & $\begin{array}{l}\text { The financial situation of the company can increase the } \\
\text { incentive to manage companies in difficulty (JOHNSON; } \\
\text { KHURANA; REYNOLD, 2002). }\end{array}$ & $(C$ Liabilities + LT Liabilities $) /$ Total Assets ${ }_{\mathrm{t}}$ \\
\hline Cash flow & $\begin{array}{l}\text { Companies with high operating cash flow are more likely to } \\
\text { perform better and because, on average, accruals and cash flow } \\
\text { are negatively related (MYERS, J.; MYERS, L.; OMER, 2003). }\end{array}$ & Operational Cash Flow $_{\mathrm{t}}$ / Average Total Assets $\mathrm{t}_{\mathrm{t}}$ \\
\hline Growth & $\begin{array}{l}\text { It captures the possible difference in the behavior of accruals } \\
\text { between companies with high and low growth (GUL; FUNG; } \\
\text { JAGGI, 2009). }\end{array}$ & $\begin{array}{l}\text { Net operating Revenue } e_{t} / \text { Net operating Revenue } e_{t-1} \\
-1\end{array}$ \\
\hline Loss & $\begin{array}{l}\text { Controlled by companies with financial difficulties, once these } \\
\text { companies are more likely to use discretionary accruals (KIM; } \\
\text { LEE, LEE, 2015) }\end{array}$ & $\begin{array}{l}\text { Dummy. Takes value } 1 \text { if the company presented a } \\
\text { loss in the period, and } 0 \text { otherwise. }\end{array}$ \\
\hline Gross margin & Used as a measure of competitiveness. & Gross Profit $_{t} /$ Net operating Revenue $_{t}$ \\
\hline Operational Cycle & $\begin{array}{l}\text { Longer operating cycles indicate more uncertainties, more } \\
\text { estimates and estimation errors, and, thus, lower earnings } \\
\text { quality (DECHOW; DICHEV, 2002). }\end{array}$ & Log of operational cycle. \\
\hline Sector & $\begin{array}{l}\text { The characteristics of each sector differ, and these characteristics } \\
\text { can influence the measure of the earnings quality. }\end{array}$ & $\begin{array}{l}\text { Dummy. } 19 \text { sectors according to the sector } \\
\text { classification of Economática. }\end{array}$ \\
\hline
\end{tabular}




\subsection{Descriptive Statistic}

Table 1 shows the number of observations, mean, standard deviation and the maximum and minimum value of each variable.

We can observe in Table 1 that the discretionary accruals calculated by the modified Jones and the Jones models have an average higher than those calculated using the Dechow and Dichev model and the McNichols model, showing the differences between the models. We can also observe that accrualJ and accrualJM have higher observations compared to accrualDD and accrualMN due to the calculation model. Audit variables evidence that on average $21.72 \%$ of observations in the period refer to exercises in which audit rotation occurred - on average, $13.30 \%$ of all observations refer to voluntary exchange. Another aspect that draws attention refers to the massive presence of companies termed as Big Four, responsible for $76.46 \%$ of audits.

To test the strength of the relationship between two variables, we performed correlation tests. Non-tabulated results demonstrated that there is a strong correlation between accrualJ and accrualJM of 0.9674 and also between accrualDD and accrualMN of 0.89893 . These results showed that the original models and their respective modified models are highly correlated. On the other hand, by observing the results of the correlation between the variables accrualDD and accrualJ, accrualDD and accrualJM, accrualMN and accrualJ, accrual$\mathrm{MN}$ and accrualJM, we identify a weak correlation between the variables, varying between 0.2967 and 0.2887 . These results evidence the existence of a low correlation between the models that capture the earnings management and those that capture the estimation errors.

Table 1. Descriptive Statistic

\begin{tabular}{lccccc}
\hline \multicolumn{1}{c}{ Variable } & Observations & Mean & Standard Deviation & Min. Value & Max. Value \\
\hline accrualJ & 1418 & 0.0776864 & 0.1192626 & 0.0000425 & 1.783887 \\
accrualJM & 1418 & 0.0794909 & 0.1215548 & 0.0000636 & 1.80542 \\
accrualD & 1046 & 0.0663311 & 0.0769704 & 0.0000238 & 0.6695541 \\
accrualMN & 1046 & 0.0602272 & 0.070448 & 0.0002215 & 0.604634157 \\
rotation & 1436 & 0.2172702 & 0.4125317 & 0 & 1 \\
voluntary & 1436 & 0.1330084 & 0.3397021 & 0 & 1 \\
audit firm & 1436 & 0.764624 & 0.4243814 & 0 & 1 \\
tenure & 1436 & 3.12883 & 1.834088 & 1 & 9 \\
size & 1604 & 14.47534 & 1.694791 & 9.965711 & 18.98451 \\
age & 1436 & 20.05432 & 15.15991 & 1 & 78 \\
ROA & 1418 & 0.0404895 & 0.1466491 & -1.547621 & 1.109644 \\
leverage & 1436 & 0.6361214 & 0.4089747 & 0.0847335 & 6.37492 \\
cash flow & 1418 & 0.0755756 & 0.098466 & -1.17195 & 0.5098779 \\
growth & 1418 & 0.2074714 & 1.407419 & -0.9726202 & 48.02996 \\
loss & 1436 & 0.2228412 & 0.4162976 & 0 & 1 \\
gross margin & 1436 & 0.32473 & 0.2051212 & -0.5242457 & 1 \\
operational cycle & 1418 & 4.726572 & 0.8890365 & -2.05606 & 10.21618
\end{tabular}

Note: Definition of the variables: accrualJ: residuals accruals of Jones model (1991); accrualJM: residuals accruals of the Modified Jones model (1995); accrualD: residuals accruals of Dechow and Dichev model (2002); accrualMN: residuals accruals of the McNichols model (2002); rotation: dummy, takes value 1 if audit firm rotation occurred, and 0 otherwise; voluntary: dummy, takes value 1 if the rotation occurred voluntarily, and 0 if mandatory; audit firm: dummy, takes value 1 if the company is audited by a Big Four firm, and 0 otherwise; tenure: number of consecutive years in which the company maintained the same audit firm; size: log of total assets; age: number of years in which the company has been listed on the stock exchange; ROA: net profitt/total assetst-1; leverage: current liabilitiest + long-term liabilitiest/total assetst; cash flow: cash flow from operationst/average total assetst; growth: (net operating revenuet/net operating revenuet-1)-1; loss: dummy, takes value 1 if the company presented a loss in the period, and 0 otherwise; gross: profitt/net operating revenuet; operational cycle: $\log$ of the operational cycle. Source: prepared by the authors. 


\subsection{Analysis of the Results of the Regression Model}

We estimated each of the specifications using the residuals of the four accruals models. Table 2 shows the results of the specifications of regression model for the calculated earnings quality on the basis of the Jones models, in panel A, and the modified Jones, in panel B.

Tabela 2. Resultados Modelos Jones e Jones modificado

\begin{tabular}{|c|c|c|c|c|}
\hline \multicolumn{5}{|l|}{ PANEL A } \\
\hline Specification Accrual Model & (1) accrualJ & (2) accrualJ & (3) accrualJ & (4) accrualJ \\
\hline rotation & $\begin{array}{c}0.0123 \\
(0.00868)\end{array}$ & $\begin{array}{c}-0.0213^{* * *} \\
(0.00707)\end{array}$ & $\begin{array}{l}-0.0228^{* *} \\
(0.00952)\end{array}$ & $\begin{array}{l}-0.0225^{* *} \\
(0.00939)\end{array}$ \\
\hline voluntary & & $\begin{array}{c}0.0549^{* * *} \\
(0.0137)\end{array}$ & $\begin{array}{c}0.0406^{* * *} \\
(0.0135)\end{array}$ & $\begin{array}{c}0.0389^{* * *} \\
(0.0134)\end{array}$ \\
\hline audit firm & & $(0.0137)$ & $\begin{array}{c}0.0208^{* *} \\
(0.00834)\end{array}$ & $\begin{array}{l}0.0243^{* * *} \\
(0.00837)\end{array}$ \\
\hline tenure & & & $\begin{array}{l}-0.00237 \\
(0.00217)\end{array}$ & $\begin{array}{l}-0.00228 \\
(0.00216)\end{array}$ \\
\hline size & & & $\begin{array}{c}-0.0122^{* * *} \\
(0.00210)\end{array}$ & $\begin{array}{c}-0.0125^{* * *} \\
(0.00227)\end{array}$ \\
\hline age & & & $\begin{array}{c}-0.000172 \\
(0.000206)\end{array}$ & $\begin{array}{r}-0.0000779 \\
(0.000253)\end{array}$ \\
\hline ROA & & & $\begin{array}{l}0.0979 \\
(0.113)\end{array}$ & $\begin{array}{l}0.0967 \\
(0.119)\end{array}$ \\
\hline leverage & & & $\begin{array}{c}0.0863^{* * *} \\
(0.0333)\end{array}$ & $\begin{array}{l}0.0836^{* *} \\
(0.0341)\end{array}$ \\
\hline cash flow & & & $\begin{array}{c}-0.104 \\
(0.0672)\end{array}$ & $\begin{array}{l}-0.0965 \\
(0.0679)\end{array}$ \\
\hline growth & & & $\begin{array}{c}0.00196 \\
(0.00455)\end{array}$ & $\begin{array}{c}0.00182 \\
(0.00424)\end{array}$ \\
\hline loss & & & $\begin{array}{c}-0.00463 \\
(0.0144)\end{array}$ & $\begin{array}{c}-0.00238 \\
(0.0138)\end{array}$ \\
\hline gross margin & & & $\begin{array}{c}-0.00271 \\
(0.0151)\end{array}$ & $\begin{array}{c}-0.00833 \\
(0.0197)\end{array}$ \\
\hline operational cycle & & & $\begin{array}{c}0.00235 \\
(0.00339)\end{array}$ & $\begin{array}{c}-0.0105^{* *} \\
(0.00490)\end{array}$ \\
\hline sector constant & $\begin{array}{c}\text { No } \\
0.0750^{* * *} \\
(0.00337)\end{array}$ & $\begin{array}{c}\text { No } \\
0.0750^{* * *} \\
(0.00337)\end{array}$ & $\begin{array}{c}\text { No } \\
0.190^{* * *} \\
(0.0444)\end{array}$ & $\begin{array}{c}\text { Yes } \\
0.259^{* * *} \\
(0.0478)\end{array}$ \\
\hline Number of Observations & 1418 & 1418 & 1418 & 1418 \\
\hline Adjusted R2 & 0.001 & 0.011 & 0.111 & 0.132 \\
\hline F Statistic & 1.996 & 9.210 & 5.576 & 4.156 \\
\hline \multicolumn{5}{|l|}{ PANEL B } \\
\hline Specification Accrual Model & (1) accrualjM & (2) accrualJM & (3) accrualJM & (4) accrualJM \\
\hline rotation & $\begin{array}{c}0.0140 \\
(0.00895)\end{array}$ & $\begin{array}{c}-0.0184^{* *} \\
(0.00743)\end{array}$ & $\begin{array}{c}-0.0206^{* *} \\
(0.00954)\end{array}$ & $\begin{array}{c}-0.0201^{* *} \\
(0.00934)\end{array}$ \\
\hline voluntary & & $\begin{array}{c}0.0528^{* * *} \\
(0.0143)\end{array}$ & $\begin{array}{c}0.0378^{* * *} \\
(0.0139)\end{array}$ & $\begin{array}{c}0.0356^{* * *} \\
(0.0136)\end{array}$ \\
\hline audit firm & & & $\begin{array}{l}0.0242^{* * *} \\
(0.00845)\end{array}$ & $\begin{array}{l}0.0284^{* * *} \\
(0.00856)\end{array}$ \\
\hline tenure & & & $\begin{array}{l}-0.00275 \\
(0.00217)\end{array}$ & $\begin{array}{l}-0.00259 \\
(0.00216)\end{array}$ \\
\hline size & & & $\begin{array}{c}-0.0133^{* * *} \\
(0.00217)\end{array}$ & $\begin{array}{c}-0.0135^{* * *} \\
(0.00232)\end{array}$ \\
\hline age & & & $\begin{array}{c}-0.000209 \\
(0.000213)\end{array}$ & $\begin{array}{r}-0.0000855 \\
(0.000255)\end{array}$ \\
\hline
\end{tabular}




\section{BBR}

15,5

420
ROA

leverage

cash flow

growth

loss

gross margin

operational cycle

sector constant

Number of Observations

Adjusted R2

F Statistic

\begin{tabular}{|c|c|c|c|}
\hline & & $\begin{array}{c}0.110 \\
(0.106)\end{array}$ & $\begin{array}{c}0.108 \\
(0.111)\end{array}$ \\
\hline & & $\begin{array}{c}0.0862^{* * *} \\
(0.0324)\end{array}$ & $\begin{array}{l}0.0836^{* *} \\
(0.0331)\end{array}$ \\
\hline & & $\begin{array}{c}-0.129^{*} \\
(0.0666)\end{array}$ & $\begin{array}{c}-0.120^{*} \\
(0.0671)\end{array}$ \\
\hline & & $\begin{array}{c}0.00217 \\
(0.00376)\end{array}$ & $\begin{array}{c}0.00205 \\
(0.00349)\end{array}$ \\
\hline & & $\begin{array}{c}-0.00310 \\
(0.0141)\end{array}$ & $\begin{array}{c}-0.000367 \\
(0.0136)\end{array}$ \\
\hline & & $\begin{array}{c}-0.0121 \\
(0.0148)\end{array}$ & $\begin{array}{l}-0.0186 \\
(0.0189)\end{array}$ \\
\hline & & $\begin{array}{c}0.00282 \\
(0.00353)\end{array}$ & $\begin{array}{c}-0.0108^{* *} \\
(0.00484)\end{array}$ \\
\hline $\begin{array}{c}\text { No } \\
0.0764^{* * *} \\
(0.00341)\end{array}$ & $\begin{array}{c}\text { No } \\
0.0764^{* * *} \\
(0.00341)\end{array}$ & $\begin{array}{c}\text { No } \\
0.208^{* * *} \\
(0.0458)\end{array}$ & $\begin{array}{c}\text { Yes } \\
0.282^{* * *} \\
(0.0486)\end{array}$ \\
\hline 1418 & 1418 & 1418 & 1418 \\
\hline 0.002 & 0.011 & 0.117 & 0.139 \\
\hline 2.430 & 7.400 & 6.458 & 4.925 \\
\hline
\end{tabular}

Notes: Robust standard deviation (Huber-White sandwich) in parentheses

** Significant at $10 \%{ }^{* *}$ Significant at $5 \%{ }^{* * *}$ Significant at $1 \%$

Definition of the variables: accrualJ: residuals accruals of the Jones model (1991); accrualJM: residuals accruals of the Modified Jones model (1995); accrualD: residuals accruals of Dechow and Dichev model (2002); accrualMN: residuals accruals of the McNichols model (2002); rotation: dummy, takes value 1 if audit firm rotation occurred, and 0 otherwise; voluntary: dummy, takes value 1 if the rotation occurred voluntarily, and 0 if mandatory; audit firm: dummy, takes value 1 if the company is audited by a Big Four firm, and 0 otherwise; tenure: number of consecutive years in which the company maintained the same audit firm; size: log of total assets; age: number of years in which the company has been listed on the stock exchange; ROA: net profitt/total assetst-1; leverage: current liabilitiest + long-term liabilitiest/total assetst; cash flow: cash flow from operationst/average total assetst; growth: (net operating revenuet/net operating revenuet-1)-1; loss: dummy, takes value 1 if the company presented a loss in the period, and 0 otherwise; gross: profitt/net operating revenuet; operational cycle: log of the operational cycle. Estimated regression model via Ordinary Least Squares - OLS (Specification 4): $\mathrm{EQ}_{\mathrm{it}}=\alpha+\beta_{1}$ Rotation $_{\mathrm{it}}+$ $\beta_{2}$ Voluntary $_{\text {it }}+\beta_{3}$ AuditFirm $_{\text {it }}+\beta_{4}$ Tenure $_{i t}+\beta_{5}$ Size $_{\text {it }}+\beta 6$ Age $_{\text {it }}+\beta 7$ ROA $_{i t}+\beta_{8}$ Leverage $_{\text {it }}+\beta_{9}$ CashFlow $_{\text {it }}+\beta_{10}$ Growth $_{\text {it }}$ $+\beta_{11}$ Loss $_{\text {it }}+\beta_{12}$ GrossMargin $_{\mathrm{it}}+\beta_{13}$ OperacionalCycle $_{\mathrm{it}}+\beta_{14}$ Sector $_{\mathrm{it}} \ldots \beta_{31}$ Sector $_{\mathrm{it}}+\varepsilon_{\mathrm{it}}$. Source: prepared by the authors.

Table 2 shows that the rotation variable is negative and significant at the $1 \%$ and $5 \%$ level for three of the four specifications of the regression model, specifications (2), (3) and (4). We observe this relationship both when the earnings quality is calculated by the Jones model and the earnings quality calculated by the modified Jones model. The negative and significant relationship between the rotation variable and the earnings quality variable evidence that auditing firm rotation contributes to reducing the volume of discretionary accruals and, consequently, increases the earnings quality.

In turn, the voluntary variable presented a positive and significant sign at the $1 \%$ level for all specifications of the regression model, using the two measures of earnings quality. This relationship shows that the voluntary exchange of audit firms increases discretionary accruals, reducing the earnings quality.

By putting the results of the rotation and voluntary variables together, we have that the occurrence of audit firm rotation reduces discretionary accruals; however, the occurrence of audit firm change voluntarily increases discretionary accruals. In summary, we can conclude that the mandatory audit firm rotation contributes to the increase of the earnings quality, whereas the voluntary exchange of the audit firm contributes to the reduction of the disclosed earning quality.

Regarding the control variables, we note that the relationship evidenced by the audit firm variable suggests that companies audited by a Big Four manage their results more 
than those audited by a Non-Big Four. The literature suggests that the Big Four tend to be more conservative and, consequently, limit the extreme accruals (MYERS, J.; MYERS, L.; OMER, 2003); however, we did not find this relationship when using accrualJ and accrualJM in this research. We should also emphasize that the results of the size and leverage variables indicate that larger companies have a lower volume of discretionary accruals, while companies with greater leverage have a greater volume of discretionary accruals.

Table 3 presents the results of the specifications for the earnings quality measured by the Dechow and Dichev models, in panel A, and McNichols, in panel B.

Table 3. Results Dechow and Dichev and McNichols Models

\begin{tabular}{|c|c|c|c|c|}
\hline \multicolumn{5}{|l|}{ PANEL A } \\
\hline Specification Accrual Model & (1) accrualJ & (2) accrualJ & (3) accrualJ & (4) accrualJ \\
\hline rotation & $\begin{array}{c}-0.00252 \\
(0.00575)\end{array}$ & $\begin{array}{c}-0.0170^{* *} \\
(0.00666)\end{array}$ & $\begin{array}{c}-0.00782 \\
(0.00747)\end{array}$ & $\begin{array}{c}-0.00444 \\
(0.00733)\end{array}$ \\
\hline voluntary & & $\begin{array}{l}0.0254^{* * *} \\
(0.00966)\end{array}$ & $\begin{array}{c}0.0112 \\
(0.00872)\end{array}$ & $\begin{array}{c}0.00563 \\
(0.00884)\end{array}$ \\
\hline audit firm & & $(0.00966)$ & $\begin{array}{l}(0.00872) \\
-0.0174^{* *}\end{array}$ & $\begin{array}{l}(0.00884) \\
-0.0168^{* *}\end{array}$ \\
\hline tenure & & & $\begin{array}{c}(0.00750) \\
0.00112\end{array}$ & $\begin{array}{c}(0.00778) \\
0.00149\end{array}$ \\
\hline size & & & $\begin{array}{c}(0.00161) \\
-0.00808^{* * *}\end{array}$ & $\begin{array}{c}(0.00156) \\
-0.00908^{* * *}\end{array}$ \\
\hline age & & & $\begin{array}{c}(0.00158) \\
-0.000137\end{array}$ & $\begin{array}{l}(0.00193) \\
0.000166\end{array}$ \\
\hline ROA & & & $\begin{array}{c}(0.000148) \\
0.104^{* *}\end{array}$ & $\begin{array}{c}(0.000168) \\
0.104^{* *}\end{array}$ \\
\hline leverage & & & $\begin{array}{l}0.0399^{* * *} \\
(0.00978)\end{array}$ & $\begin{array}{l}0.0345^{* * *} \\
(0.00905)\end{array}$ \\
\hline cash flow & & & $\begin{array}{c}-0.000361 \\
(0.0409)\end{array}$ & $\begin{array}{r}-0.00519 \\
(0.0392)\end{array}$ \\
\hline growth & & & $\begin{array}{c}0.00328 \\
(0.00239)\end{array}$ & $\begin{array}{c}0.00314 \\
(0.00210)\end{array}$ \\
\hline loss & & & $\begin{array}{c}0.0142^{*} \\
(0.00757)\end{array}$ & $\begin{array}{c}0.0167^{* *} \\
(0.00710)\end{array}$ \\
\hline gross margin & & & $\begin{array}{c}-0.0338^{* * *} \\
(0.0123)\end{array}$ & $\begin{array}{c}-0.0388^{* * *} \\
(0.0148)\end{array}$ \\
\hline operational cycle & & & $\begin{array}{l}0.00786^{* *} \\
(0.00354)\end{array}$ & $\begin{array}{c}0.00408 \\
(0.00427)\end{array}$ \\
\hline sector constant & $\begin{array}{c}\text { No } \\
0.0669^{* * *} \\
(0.00270)\end{array}$ & $\begin{array}{c}\text { No } \\
0.0669^{* * *} \\
(0.00270)\end{array}$ & $\begin{array}{c}\text { No } \\
0.137^{* * *} \\
(0.0324)\end{array}$ & $\begin{array}{c}\text { Yes } \\
0.153^{* * *} \\
(0.0385)\end{array}$ \\
\hline Number of Observations & 1046 & 1046 & 1046 & 1046 \\
\hline Adjusted R2 & -0.001 & 0.004 & 0.137 & 0.181 \\
\hline F Statistic & 0.192 & 4.258 & 7.602 & 4.940 \\
\hline \multicolumn{5}{|l|}{ PANEL B } \\
\hline Specification Accrual Model & (1) accrualJM & (2) accrualjM & (3) accrualJM & (4) accrualJM \\
\hline rotation & $\begin{array}{c}-0.00445 \\
(0.00488)\end{array}$ & $\begin{array}{c}-0.0118^{*} \\
(0.00669)\end{array}$ & $\begin{array}{c}-0.00373 \\
(0.00737)\end{array}$ & $\begin{array}{c}-0.000706 \\
(0.00726)\end{array}$ \\
\hline voluntary & & $\begin{array}{c}0.0128 \\
(0.00834)\end{array}$ & $\begin{array}{c}0.00107 \\
(0.00782)\end{array}$ & $\begin{array}{r}-0.00405 \\
(0.0081)\end{array}$ \\
\hline audit firm & & & $\begin{array}{c}-0.0188^{* * *} \\
(0.00664)\end{array}$ & $\begin{array}{c}-0.0181^{* * *} \\
(0.00689)\end{array}$ \\
\hline tenure & & & $\begin{array}{l}0.000821 \\
(0.00151)\end{array}$ & $\begin{array}{c}0.0012 \\
(0.00146)\end{array}$ \\
\hline
\end{tabular}

Continued 


\section{BBR}

15,5

422 size

age

ROA

leverage

cash flow

growth

loss

gross margin

operational cycle

sector constant

Number of Observations

Adjusted R2

F Statistic

\begin{tabular}{|c|c|}
\hline $\begin{array}{c}-0.00711^{* * *} \\
(0.00138)\end{array}$ & $\begin{array}{c}-0.00772^{* * *} \\
(0.00167)\end{array}$ \\
\hline $\begin{array}{c}-0.0000261 \\
(0.000131)\end{array}$ & $\begin{array}{c}0.000192 \\
(0.000151)\end{array}$ \\
\hline $\begin{array}{l}0.144^{* * *} \\
(0.0376)\end{array}$ & $\begin{array}{l}0.144^{* * *} \\
(0.0379)\end{array}$ \\
\hline $\begin{array}{c}0.0477^{* * *} \\
(0.01)\end{array}$ & $\begin{array}{l}0.0452^{* * *} \\
(0.00909)\end{array}$ \\
\hline $\begin{array}{c}-0.000026 \\
(0.0428)\end{array}$ & $\begin{array}{c}0.00345 \\
(0.043)\end{array}$ \\
\hline $\begin{array}{l}-0.00169^{*} \\
(0.000946)\end{array}$ & $\begin{array}{c}-0.00171^{* *} \\
(0.000844)\end{array}$ \\
\hline $\begin{array}{c}0.0156^{* *} \\
(0.00672)\end{array}$ & $\begin{array}{l}0.0175^{* * *} \\
(0.00659)\end{array}$ \\
\hline $\begin{array}{c}-0.0414^{* * *} \\
(0.0113)\end{array}$ & $\begin{array}{c}-0.0475^{* * *} \\
(0.0136)\end{array}$ \\
\hline $\begin{array}{c}0.00623^{* *} \\
(0.00294)\end{array}$ & $\begin{array}{c}0,00268 \\
(0.00355)\end{array}$ \\
\hline $\begin{array}{c}\text { No } \\
0.121^{* * *} \\
(0.0279)\end{array}$ & $\begin{array}{c}\text { Yes } \\
0.139^{* * *} \\
(0.0328)\end{array}$ \\
\hline 1046 & 1046 \\
\hline 0.181 & 0.21 \\
\hline 8.139 & 5.529 \\
\hline
\end{tabular}

Notes: Robust standard deviation (Huber-White sandwich) in parentheses.

* Significant at $10 \%{ }^{* *}$ Significant at 5\% *** Significant at $1 \%$

Definition of the variables: accrualJ: residuals accruals of the Jones model (1991); accrualJM: residuals accruals of the Modified Jones model (1995); accrualD: residuals accruals of Dechow and Dichev model (2002); accrualMN: residuals accruals of the McNichols model (2002); rotation: dummy, takes value 1 if audit firm rotation occurred, and 0 otherwise; voluntary: dummy, takes value 1 if the rotation occurred voluntarily, and 0 if mandatory; audit firm: dummy, takes value 1 if the company is audited by a Big Four firm, and 0 otherwise; tenure: number of consecutive years in which the company maintained the same audit firm; size: log of total assets; age: number of years in which the company has been listed on the stock exchange; ROA: net profitt/total assetst-1; leverage: current liabilitiest + long-term liabilitiest/total assetst; cash flow: cash flow from operationst/average total assetst; growth: (net operating revenuet/net operating revenuet-1)-1; loss: dummy, takes value 1 if the company presented a loss in the period, and 0 otherwise; gross: profitt/net operating revenuet; operational cycle: log of the operational cycle.

Estimated regression model via OrdinaryLeastSquares - OLS (Specification 4): $\mathrm{EQ}_{\mathrm{it}}=\alpha+\beta_{1}$ Rotation $_{\mathrm{it}}+\beta_{2}$ Voluntary $_{\mathrm{it}}$ $+\beta_{3}$ AuditFirm $_{\mathrm{it}}+\beta_{4}$ Tenure $_{\mathrm{it}}+\beta_{5}$ Size $_{\mathrm{it}}+\beta_{6}$ Age $_{\mathrm{it}}+\beta_{7}$ ROA $_{\mathrm{it}}+\beta_{8}$ Leverage $_{\mathrm{it}}+\beta_{9}$ CashFlow $_{\mathrm{it}}+\beta_{10}$ Growth $_{\mathrm{it}}+\beta_{11}$ Loss $_{\mathrm{it}}+$

$\beta_{12}$ GrossMargin $_{\text {it }}+\beta_{13}$ OperacionalCycle $_{\text {it }}+\beta_{14}$ Sector $_{\text {it }} \ldots \beta_{31}$ Sector $_{\text {it }}+\varepsilon_{\text {it }}$

Differently from the previous results, the results of Table 3 do not allow us to affirm that the audit firm rotation affects the earnings quality, when the quality is measured by accrualDD and accrualMN. This rotation variable, which identifies the occurrence of the audit firm change, presents statistically significant results only for the specification (2) and non-statistically significant results for the others. However, we note that, when statistically significant, the rotation variable presented a negative coefficient, indicating that the occurrence of audit firm rotation reduces the volume of discretionary accruals. The same signal was presented by the coefficients of the rotation variable in Table 2.

The voluntary variable, which shows whether the change of audit firm occurred on a voluntary or mandatory basis, was only statistically significant in the specification (2) for accrualDD. In this case, the positive coefficient of the voluntary variable evidenced that the occurrence of voluntary audit firm rotation increases the volume of discretionary accruals, reducing the earnings quality. For accrualMN, the voluntary variable did not present statistical significance in any specification, as can be observed in Table 3. 
By considering the results presented in Table 2 and Table 3, we can infer that audit rotation contributes to restricting the earnings management, measured by the accrualJ and accrualJM, but not to reduce the errors of estimates, as measured by accrualDD and accrualMN. This is because while the rotation and mandatory variables have appeared to be significant in specifications (2), (3) and (4) for accrualJ and accrualJM, they demonstrated to be significant only for specification (2) for accrualDD, and for accrualMN, only the rotation demonstrated to be statistically significant in specification (2). In summary, when residual accruals that identify intentional errors are used, the rotation and the voluntary variables are significant, whereas when used as a measure of estimation errors, regardless of whether or not it is intentional, this relationship is not clearly evidenced.

In addition, Table 3 demonstrates that the audit firm variable is statistically significant at the $1 \%$ and $5 \%$ level. In this case, the audit firm assumes a negative coefficient, as expected based on the previous literature. We conclude that the auditing firms denominated Big Four reduce the errors of accounting estimates, when these are not segregated between intentional or unintentional. When we approach only the perspective of intentional errors, the effect of the audit firm on the earnings quality is contrary. In relation to the other control variables we note that size, ROA, leverage, loss and gross margin presented statistically significant results for all specifications.

\subsection{Additional Tests}

In sequence, we estimated all the specifications of the regression model for the subsequent period, that is, the variable earnings quality took the value of the residuals accruals of year $t+1$, while the other variables remained in relation to year $t$. Therefore, we analyzed the effect of audit firm rotation on the earnings quality of the year subsequent to the rotation.

Firstly, because we considered that the year of the rotation could represent a period of adaptation of the audit firm in relation to the activities of the company. Thus, when analyzing the effect of audit rotation on the earnings quality of the subsequent year, we expected to minimize the influence of the lack of knowledge about the company's activities, often mentioned in the literature. Secondly, because we identified in the reference form disclosed by the companies on the BM\&FBOVESPA website that, many of the audit contracts do not coincide with the company's fiscal year. Although the auditors are hired to express an opinion on all accounting statements for the year, we believe that hiring the audit firm after the beginning of the fiscal year may influence the recording of accounting operations. This is because in the period of registration of operations, the company does not have full knowledge of the position of the audit in relation to certain accounting practices.

The non-tabulated results of the subsequent period demonstrated that the rotation variable remains negative and statistically significant at different levels of significance in specifications (2), (3) and (4) for both accrualJ and accrualJM. Likewise, the voluntary variable maintains the positive sign and is statistically significant in all specifications. Regarding the estimation errors, two specifications of the regression model presented negative and a statistically significant sign for the rotation variable when the earnings quality was measured by accrualDD. By using the same accrual model, the voluntary variable presented a positive and statistically significant sign in the specifications (2) and (3). Thus, when we use accrualDD, the relationship between audit rotation and the reason for the change, with the earnings quality, is more evident in the subsequent 
BBR

15,5

424

period than in the contemporary period. For the accrualMN, rotation is only significant for the specification (2), the same for voluntary rotation, limiting the conclusions about these variables.

We should note that the contemporary and subsequent periods present convergent results. Thus, we believe that the results of the subsequent period give robustness to the research findings, evidenced in the contemporary period.

\section{Conclusion}

The results show that the auditing firm rotation reduces the volume of discretionary accruals, when we measure these by the Jones and the modified Jones models. However, the effect of auditing firm rotation on the earnings quality was not evident when we measured discretionary accruals by the Dechow and Dichev and McNichols models. This suggests that we can consider the mandatory audit firm rotation as a mechanism that contributes to the reduction of the earnings management, but not of the estimation errors.

In addition, the reason for the exchange demonstrated to be an important feature of the rotation, since the results showed that the voluntary audit firm rotation increases discretionary accruals. This means that, unlike compulsory rotation, the voluntary exchange of audit firm reduces earnings quality.

Based on the results, we do not reject hypothesis $\mathrm{H} 1$ that earnings quality increases with the mandatory audit firm rotation. However, the results are limited to accruals models that capture earnings management. On the other hand, we rejected hypothesis $\mathrm{H} 2$, that earnings quality by companies increases with the voluntary audit firm rotation.

The results of the research contribute to the literature for presenting results based on a scenario of regulated audit firm rotation, unlike most international research that are carried out in unregulated scenarios. The results allow different conclusions from those made by Chen, Lin and Lin (2008); Johnson, Khurana and Reynold (2002) and Myers, J., Myers, L. and Omer (2003) who concluded that the increase in the relationship between the audit firm and the company does not lead to a reduction in earnings quality. On the other hand, the findings of the present study present evidences favorable to the mandatory audit firm rotation, as well as in the research of Kim, Lee and Lee (2015).

Considering the Brazilian studies, the present research presents new results, different from those evidenced by Azevedo and Costa (2012); Martinez and Reis (2011); Silva and Bezerra (2010) who concluded that there is no evidence of the association between earnings management and audit rotation. However, although Silva and Bezerra (2010) have concluded that the change of audit firm is not directly related to the decrease in the earnings management, some sectors of the research have tended to do so.

The present research adds new evidence seeking to foment the discussions about the mandatory audit firm rotation. It should be emphasized, however, that we should carefully consider the results should, since they are limited to the defined earnings quality metrics, the discretionary accruals models used, as well as the sample and the period studied. Not only did we reduce the sample due to unavailable information, as the period also coincides with several normative changes in the accounting area and in the economic cycle of the companies. These changes were partially captured when we estimated the residuals year by year, as explained in the methodology, and by introducing various economic, financial and sector controls. The low explanatory power of the regression model evidenced by Adjusted $\mathrm{R} 2$, while evidencing the need to use these controls, points out that other aspects not considered in this research can influence the earnings quality. Thus, we suggest that future research on the effect of audit firm rotation on the earnings quality investigates other aspects not 
addressed in this study, such as, issues related to corporate governance and characteristics of the structure of control and ownership of companies.

\section{REFERENCES}

ANINAT, Antonio; BUSTOS, Álvaro E.; RIUTORT, Julio. The Effects of Audit Firms Rotation: An Event Study in Chile. 2016.

ASSUNÇÃO, Juliano; CARRASCO, Vinicius. Avaliação da rotatividade dos auditores independentes. Rio de Janeiro: Departamento de Economia da Pontifica Universidade Católica do Rio de Janeiro, 2008.

AZEVEDO, Filipe Bressanelli; COSTA, Fábio Moraes da. Efeito da troca da firma de auditoria no gerenciamento de resultados das companhias abertas brasileiras. Revista de Administração Mackenzie, São Paulo, v. 13, n. 5, 2012.

BAXTER, Peter; COTTER, Julie. Audit committees and earnings quality. Accounting \& Finance, [S.1.], v. 49, n. 2, p. 267-290, 2009.

CARCELLO, Joseph V.; NAGY, Albert L. Audit firm tenure and fraudulent financial reporting. Auditing: a journal of practice \& theory, [S.1.], v. 23, n. 2, p. 55-69, 2004.

CAREY, Peter; SIMNETT, Roger. Audit partner tenure and audit quality. The Accounting Review, [S.1.], v. 81, n. 3, p. 653-676, 2006.

CHAN, Konan et al. Earnings quality and stock returns. The Journal of Business, [S.1.], v. 79, n. 3, p. 10411082, 2006.

CHEN, Chih Ying; LIN, Chan Jane; LIN, Yu Chen. Audit partner tenure, audit firm tenure, and discretionary accruals: does long auditor tenure impair earnings quality? Contemporary Accounting Research, [S.1.], v. 25 , n. 2, p. 415-445, 2008.

COMISSÃO DE VALORES MOBILIÁRIOS (CVM). Deliberação n. 549, 10 de setembro de 2008. Dispõe sobre a rotatividade dos auditores independentes na prestação de serviços de auditoria independente de demonstrações contábeis para um mesmo cliente, no âmbito do mercado de valores mobiliários. Disponível em: $<$ http://www. cvm. gov.br $>$. Acesso em: 28 jun. 2015.

COMISSÃO DE VALORES MOBILIÁRIOS (CVM). Instrução n. 308, 14 de maio de 1999. Registro e Exercício da Atividade de Auditoria Independente. Disponível em: $<$ http://www. cvm. gov.br $>$. Acesso em: 28 jun. 2015.

CONSELHO FEDERAL DE CONTABILIDADE (CFC). NBC TA 700, de 17 de junho de 2016. Formação da Opinião e Emissão do Relatório do Auditor Independente sobre as Demonstrações Contábeis. Disponível em: < http://www.portalcfc.org.br/wordpress/wpcontent/uploads/2012/12/NBC_TA_05112012.pdf . Acesso em: 06 ago. 2016.

DAVIS, Larry R.; SOO, Billy S.; TROMPETER, Gregory M. Auditor tenure and the ability to meet or beat earnings forecasts. Contemporary Accounting Research, [S.1.], v. 26, n. 2, p. 517-548, 2009.

DECHOW, Patricia M.; DICHEV, Ilia D. The quality of accruals and earnings: The role of accrual estimation errors. The Accounting Review, [S.1.], v. 77, n. s-1, p. 35-59, 2002.

DECHOW, Patricia M.; SLOAN, Richard G.; SWEENEY, Amy P. Detecting earnings management. Accounting Review, [S.1.], p. 193-225, 1995.

DECHOW, Patricia; GE, Weili; SCHRAND, Catherine. Understanding earnings quality: A review of the proxies, their determinants and their consequences. Journal of Accounting and Economics, [S.1.], v. 50, n. 2, p. 344-401, 2010.

DEFOND, Mark L.; SUBRAMANYAM, K. R. Auditor changes and discretionary accruals. Journal of Accounting and Economics, [S.1.], v. 25, n. 1, p. 35-67, 1998.

DELOITTE. Governance in brief: EU position on auditor rotation goes further than UK rules. London, 2014. Disponível em: <https://www2.deloitte.com/content/dam/ Deloitte/uk/Documents/audit/deloitte-uk-audit-governance-in-brief-eu-position-on-auditor-rotation-goes-further-than-uk-rules.pdf $>$. Acesso em: 02 set. 2016.

EISENHARDT, Kathleen M. Agency theory: An assessment and review. Academy of Management Review, [S.1.], v. 14, n. 1, p. 57-74, 1989.

FRANCIS, Jennifer et al. The market pricing of accruals quality. Journal of Accounting and Economics, [S.1.], v. 39, n. 2, p. 295-327, 2005.

GHOSH, Aloke; MOON, Doocheol. Auditor tenure and perceptions of audit quality. The Accounting Review, [S.1.], v. 80, n. 2, p. 585-612, 2005. 
BBR

15,5
GUL, Ferdinand A.; FUNG, Simon Yu Kit; JAGGI, Bikki. Earnings quality: Some evidence on the role of auditor tenure and auditors' industry expertise. Journal of Accounting and Economics, [S.1.], v. 47, n. 3, p. 265-287, 2009.

HARRIS, Kathleen; WHISENANT, Scott. Mandatory audit rotation: an international investigation. University of Houston, 2012.

INSTITUTO DOS AUDITORES INDEPENDENTES DO BRASIL (IBRACON). O rodízio de firmas de auditoria. São Paulo, 20 jan. 2014. Disponível em: <http://www.ibracon.com.br/ibracon/Portugues/detNoticia.php?cod=1626>. Acesso em: 20 ago. 2016.

JENKINS, David S.; VELURY, Uma K. Auditor tenure and the pricing of discretionary accruals in the post-SOX era. Accounting and the Public Interest, [S.1.], v. 12, n. 1, p. 1-15, 2012.

JENSEN, Michael C.; MECKLING, William H. Theory of the firm: Managerial behavior, agency costs and ownership structure. Journal of Financial Economics, [S.1.], v. 3, n. 4, p. 305-360, 1976.

JOHNSON, Van E.; KHURANA, Inder K.; REYNOLDS, J. Kenneth. Audit Firm Tenure and the Quality of Financial Reports. Contemporary Accounting Research, [S.1.], v. 19, n. 4, p. 637-660, 2002.

JONES, Jennifer J. Earnings management during import relief investigations. Journal of Accounting Research, [S.1.], p. 193-228, 1991.

KIM, Hakwoon; LEE, Hyoik; LEE, Jong Eun. Mandatory audit firm rotation and audit quality. Journal of Applied Business Research, [S.1.], v. 31, n. 3, p. 1089-1106, 2015.

KRISHNAN, Gopal V. Audit quality and the pricing of discretionary accruals. Auditing: A Journal of Practice \& Theory, [S.1.], v. 22, n. 1, p. 109-126, 2003.

MARTINEZ, Antonio Lopo; REIS, Graciela Mendes Ribeiro. Rodízio das firmas de auditoria e o gerenciamento de resultados no Brasil. Revista de Contabilidade e Organizações, [S.1.], v. 4, n. 10, p. 48-64, 2011.

MCNICHOLS, Maureen F. Discussion of the quality of accruals and earnings: the role of accrual estimation errors. The Accounting Review, [S.1.], v. 77 (Supplement), p. 61-69, 2002.

MYERS, James N.; MYERS, Linda A.; OMER, Thomas C. Exploring the term of the auditor-client relationship and the quality of earnings: A case for mandatory auditor rotation? The Accounting Review, [S.1.], v. 78, n. 3, p. 779-799, 2003.

PIOT, Charles. Agency costs and audit quality: evidence from France. European Accounting Review, [S.1.], v. 10, n. 3, p. 461-499, 2001.

SCHIPPER, Katherine; VINCENT, Linda. Earnings quality. Accounting Horizons, [S.1.], v. 17, p. $97,2003$.

SILVA, Júlio Orestes da; BEZERRA, Francisco Antonio. Análise do gerenciamento de resultados e o rodízio de firmas de auditoria nas empresas de capital aberto. Revista Brasileira de Gestão de Negócios, São Paulo, v. 12 , n. 36, p. 304, 2010. 